\title{
Export, biodegradation, and disinfection byproduct formation of dissolved and particulate organic carbon in a forested headwater stream during extreme rainfall events
}

\author{
B.-J. Jung ${ }^{1}$, J.-K. Lee ${ }^{1}$, H. Kim ${ }^{2}$, and J.-H. Park ${ }^{3,4}$ \\ ${ }^{1}$ Department of Forest Environment Protection, Kangwon National University, Chuncheon 200-701, Republic of Korea \\ ${ }^{2}$ Department of Environmental Science, Kangwon National University, Chuncheon 200-701, Republic of Korea \\ ${ }^{3}$ Department of Environmental Science and Engineering, Ewha Womans University, Seoul 120-750, Republic of Korea \\ ${ }^{4}$ Global Top 5 Project, Ewha Womans University, Seoul 120-750, Republic of Korea
}

Correspondence to: J.-H. Park (jhp@ewha.ac.kr)

Received: 10 February 2014 - Published in Biogeosciences Discuss.: 14 May 2014

Revised: 5 October 2014 - Accepted: 7 October 2014 - Published: 13 November 2014

\begin{abstract}
Despite an increasing recognition of the importance of extreme rainfall events for organic carbon export to inland waters, little attention has been paid to the export and reactivity of particulate organic carbon (POC) and dissolved organic $\mathrm{C}$ (DOC) in mountainous headwater watersheds under monsoon climates. To investigate environmental implications of storm-enhanced export of POC and DOC in mountainous headwater streams, we examined the relationships between storm magnitude and $\mathrm{C}$ export from a forested watershed in the Haean Basin, South Korea, during 13 storm events over 4 years and compared potentials of DOC and POC for biodegradation and disinfection byproduct (DBP) formation during an extreme rainfall event with a total rainfall of $209 \mathrm{~mm}$. Event mean concentrations and export of POC increased nonlinearly above thresholds of precipitation and discharge, far exceeding the relatively small increases of DOC. The export of POC during a few storm events with a total rainfall above $200 \mathrm{~mm}$ per event exceeded the annual organic C export during dry years. During the $209 \mathrm{~mm}$ storm event, concentrations of total trihalomethanes formed by POC-derived dissolved components changed synchronously with POC concentrations, exhibiting lower levels than those formed by DOC. During a 30-day incubation at $25^{\circ} \mathrm{C}$, DOC exported during peak flow exhibited rapid biodegradation of labile components within 7 days. In contrast, the concentrations of DOC leached from POC gradually increased following the initial decline. Gradual transformation of POCderived dissolved materials resulted in greater increases in
\end{abstract}

the intensity of fulvic- and humic-like fluorescent components compared to the DOC treatment. The results highlight the significance of extreme rainfall events as "hot moments" for POC export from mountainous watersheds and also suggest that storm pulses of POC can provide potential sources of reactive organic components that can rapidly biodegrade and form DBPs after being released into headwater streams.

\section{Introduction}

The transport of dissolved organic C (DOC) and particulate organic carbon (POC) along streams and rivers represents a crucial linkage between land and oceans in the global $\mathrm{C}$ cycle (Cole et al., 2007; Battin et al., 2008; Aufdenkampe et al., 2011). Earlier estimates of the quantity of riverine organic $\mathrm{C}$ transport to the oceans range from 0.19 to $0.33 \mathrm{Pg} \mathrm{C}$, and have often been neglected in global $\mathrm{C}$ budgets because they constitute only 1 to $2 \%$ of the net primary production of terrestrial ecosystems (Meybeck, 1982). Recent syntheses have provided higher estimates for the riverine $\mathrm{C}$ export, ranging from 0.8 to $0.9 \mathrm{Pg} \mathrm{C}$, and it has been suggested that the amount of $\mathrm{C}$ delivered to the oceans might represent only a fraction of the total $\mathrm{C}$ received by inland waters (Battin et al., 2009; Aufdenkampe et al., 2011). After receiving up to $2.7 \mathrm{Pg} \mathrm{C}$ from terrestrial sources, inland waters do not transport it passively, but process it, and return substantial amounts of $\mathrm{C}$ to the atmosphere either as $\mathrm{CO}_{2}$ (Mayorga 


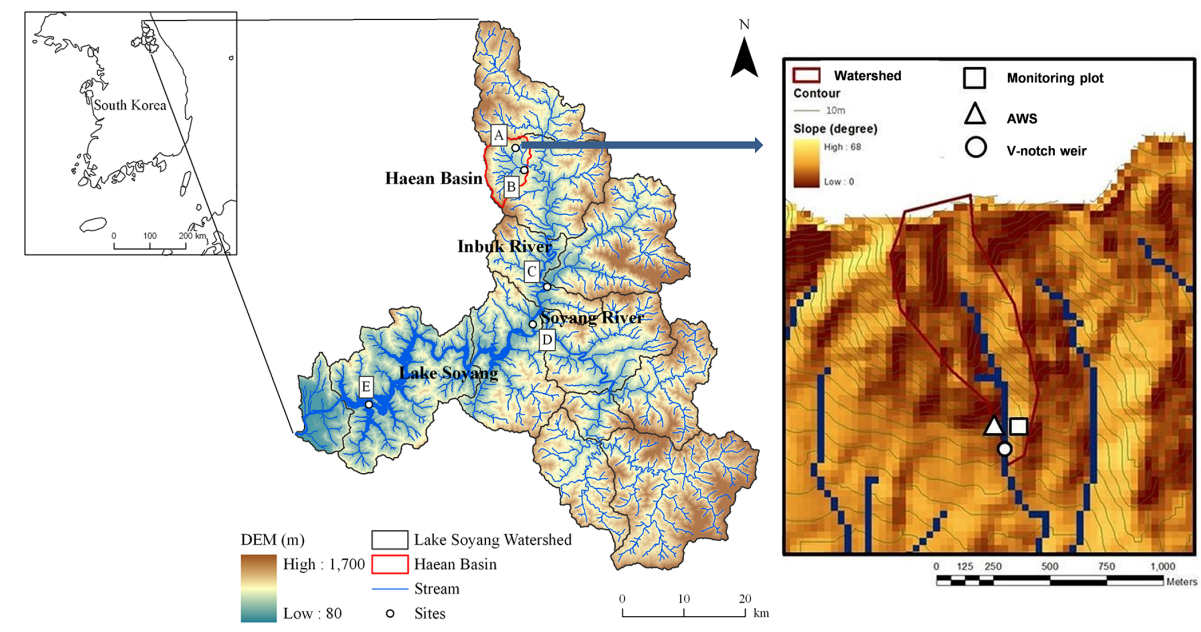

Figure 1. Monitored headwater watershed (right) within the Haean Basin in the Lake Soyang watershed, South Korea (left; "A" indicates the location of the headwater watershed in the Haean Basin).

et al., 2005; Raymond et al., 2013) or as $\mathrm{CH}_{4}$ (Bastviken et al., 2011). Other studies have suggested a high $\mathrm{C}$ sequestration potential of inland water systems including reservoirs, lakes, and floodplains (Stallard, 1998; Syvitski et al., 2005; Van Oost et al., 2007; Goldsmith et al., 2008; Zehetner et al., 2009). Although studies conducted in steep terrain such as the Himalayas have assumed mountainous rivers as a pipe transferring organic $\mathrm{C}$ passively to the ocean and resulting in a preservation of terrigenous $\mathrm{C}$ in bottom sediments along the coastal margins (Galy et al., 2007), little is known about the dynamics of POC in mountainous headwater streams receiving storm pulses of POC.

Terrestrial mobilization and riverine processing of DOC have been studied over a wide range of climate zones (del Giorgio and Davis, 2003), but less is known about the fate of POC associated with suspended and deposited sediments in inland waters and floodplains. The long-held assumption that POC is a minor component of aquatic organic $\mathrm{C}$ is based on observations of large rivers, as exemplified by the high ratios of DOC to total organic carbon (TOC) between 0.6 and 0.8 found in lowland rivers (Meybeck, 1982). However, unusually high concentrations of POC that exceed DOC concentrations have been observed in low-order streams and rivers, especially during storm events (Fisher and Likens, 1973; Bilby and Likens, 1979; Wallace et al., 1995; Coynel et al., 2005; Kim et al., 2010). Recent studies employing intensive storm event sampling and high-frequency in situ instrumental measurements have demonstrated that the pulsed export of POC during very short peak flow periods of intense or extreme storms can account for a disproportionately large fraction of the annual $\mathrm{C}$ exported from headwater watersheds (Jeong et al., 2012; Jung et al., 2012; Dhillon and Inamdar, 2013).

Studies of the biodegradation and transformation of POC have focused on the leaching of dissolved organic matter (DOM) from different sources (Yoshimura et al., 2010) or the photochemically mediated conversion of DOM from suspended sediments (Riggsbee et al., 2008). Although the bulk of riverine POC at low flow has been considered aged and metabolically not reactive, it has been suggested recently that not only labile components but also recalcitrant compounds such as lignin and other phenolic compounds can be consumed rapidly by microorganisms in large tropical rivers such as the Amazon (Ward et al., 2013). Studies of POC origin and lability in some European estuaries have shown that the bulk of POC in estuaries might be refractory, whereas seasonal changes in the input of organic matter of autochthonous or anthropogenic origin can significantly increase the lability and biodegradability of POC even to a higher degree than observed for DOC (Etcheber et al., 2007; Garnier et al., 2008). It remains unexplored whether POC in headwater streams has comparable lability relative to DOC.

It was discovered in the 1970s that high levels of organic $\mathrm{C}$ in drinking water facilities can lead to the formation of carcinogenic and mutagenic disinfection byproducts (DBPs) (Rook, 1977). Much research has been conducted to characterize DOC components as DBP precursors (e.g., Chow et al., 2007; Beggs et al., 2009), but little attention has been paid to the reactive components of POC that are responsible for DBP formation. Although storm pulses of sediments have been suggested as a serious climate-induced risk to drinking water facilities (Hurst et al., 2004; Park et al., 2010), rapid conversion of labile components from POC has not yet been linked with DBP formation. The primary objective of this study was to evaluate the relative importance of POC and DOC as a source of labile, reactive organic components in headwater streams during monsoon rainfall events. First, we analyzed the relationship between storm magnitude and organic $\mathrm{C}$ export using DOC and POC data collected from a forested headwater stream in the Haean Basin, South Korea, during 13 storm events over 4 years. We also compared the 
potentials of DOC and POC, released during a large storm event with a total rainfall of $209 \mathrm{~mm}$, for biodegradation and DBP formation, to redress the view of low reactivity of POC in mountainous streams and rivers under monsoon climates.

\section{Materials and methods}

\subsection{Study site and storm event measurements}

The study was conducted at a forested watershed that represents steep headwater areas in the Haean Basin, South Korea $\left(38^{\circ} 15^{\prime}-38^{\circ} 20^{\prime} \mathrm{N} ; \quad 128^{\circ} 05^{\prime}-128^{\circ} 10^{\prime} \mathrm{E} ; \quad 400-1304 \mathrm{~m}\right.$ a.s.l.; Fig. 1). The bedrock in the Haean Basin consists of highly weathered biotite granite at lower elevations overlain by metamorphic rocks, which form the mountain ridges. The naturally regrown, mixed deciduous forest on the steep $\left(>20^{\circ}\right.$ ) slopes is dominated by Mongolian oaks (Quercus mongolica), Daimyo oaks (Quercus dentata), and Korean ashes (Fraxinus rhynchophylla). Soils typical of the forested mountain slopes are dry to slightly moist brown soils (acid Cambisols), according to the FAO (Food and Agriculture Organization of the United Nations) World Reference Base for Soil Resources, overlain by moder-like forest floors with a distinct Oi horizon and less distinct Oe/Oa horizons. The annual mean temperature at the Haean Basin is around $9{ }^{\circ} \mathrm{C}$. The mean summer (June to August) rainfall over the period from 1997 to 2010 was $939 \mathrm{~mm}$, which accounted for $61 \%$ of the mean annual precipitation of $1539 \mathrm{~mm}$ (Jeong, 2011).

Intensive storm event water samplings during the summer monsoon period were conducted upstream of the $V$ notch weir located at the outlet of the stream draining the study watershed during 13 storm events over 4 years from 2008 through 2011 (Fig. 1; refer to Jeong et al., 2012 and Jung et al., 2012 for more details about sampling methods). During the storm events, stream-water samples were usually collected every 2 hours using an autosampler (6712 portable sampler, ISCO).

Water samples were first filtered through a $2 \mathrm{~mm}$ mesh sieve to remove large particles and debris and then through a pre-combusted GF/F filter (Whatman; nominal pore size: $0.7 \mu \mathrm{m}$ ). The filters were then dried at $65^{\circ} \mathrm{C}$ to a constant weight and reweighed to calculate the total suspended solids (TSS). The dried filters were fumed with $\mathrm{HCl}$ in a sealed desiccator for $24 \mathrm{~h}$ to remove inorganic $\mathrm{C}$ prior to the analysis of POC. The concentrations of POC in the acid-treated filters were measured with an elemental analyzer (Vario MAX $\mathrm{CN}$, Elementar, Germany). The DOC concentrations in the filtered water samples were measured with a TOC analyzer using high-temperature combustion of organic matter (OM) followed by thermal detection of $\mathrm{CO}_{2}$ (TOC 5000 a or TOC $V_{\mathrm{CPH}}$, Shimadzu, Japan). For each batch of 10 samples measured for POC and DOC, we carried out continuous concentration verification with a check standard and a baseline contamination check using both the field and the laboratory blanks. As an additional measure for quality control, replicate analysis was conducted for approximately $10 \%$ of all the measured samples. The relative standard deviations for the repeated measurements of check standards were within $5 \%$.

Discharge-weighted mean concentrations and exports of DOC and POC during each of storm events were calculated using measured concentrations of DOC and POC and discharge data that were either estimated using the HBV-light hydrologic model for the period from 2008 through July 2009 or measured with a $V$ notch weir thereafter (Jung et al., 2012). Storm event periods were determined using a webbased hydrograph analysis tool (WHAT; http://cobweb.ecn. purdue.edu/ what/; Lim et al., 2005). The relationships between the measures of storm magnitude (event total precipitation or discharge) and the concentrations or fluxes of DOC and POC were examined by establishing best-fit regressions using a data analysis software (SigmaPlot, version 10.0). Hourly precipitation data were obtained from an automatic weather station located within the Haean Basin, operated by the Korea Meteorological Administration.

\subsection{Laboratory incubation experiments}

Two laboratory incubation experiments were conducted with DOM and suspended sediment (SS) samples collected during a large storm event from 22-27 June 2011 (cumulative precipitation: $209 \mathrm{~mm}$ ). According to widely used extreme precipitation indices such as upper first to fifth percentiles of 1-day or 5-day cumulative precipitation, the monitored storm event can be regarded as a "very wet" or "extremely wet" event (Choi et al., 2009). The first experiment was performed using water samples collected at five different times under different flow conditions during the first phase of the storm event to measure the DBP formation potentials of DOM and SS-derived DOM (hereafter referred to as "SSDOM"). Stream-water samples were filtered through cellulose acetate membrane filters (Whatman; nominal pore size: $0.45 \mu \mathrm{m}$ ) to separate particulates from DOM. We used membrane filters instead of GF/F filters despite the slight difference in pore size, because the latter did not allow us to scrape off particles from glass fiber. Filtered stream-water samples from five sampling points were measured for DOC concentrations. SS samples collected on the filters were transferred to ultrapure water (Milli-Q, Millipore) and then extracted for the dissolved fraction on a shaker for $1 \mathrm{~h}$. The SS extracts were again filtered through cellulose acetate membrane filters and DOC concentrations were then measured. We used blank filters without SS to check any contamination from filter materials.

Three replicates $(150 \mathrm{~mL}$ each) of DOM and SS-DOM samples were treated with $\mathrm{NaOCl}$ (final concentration after addition $\approx 4 \mathrm{mg} \mathrm{L}^{-1}$ ) in the dark at $20^{\circ} \mathrm{C}$ for $24 \mathrm{~h}$. Upon completion of incubation, samples were quenched with ascorbic acid (0.04 g per sample). Six volatile DBPs 

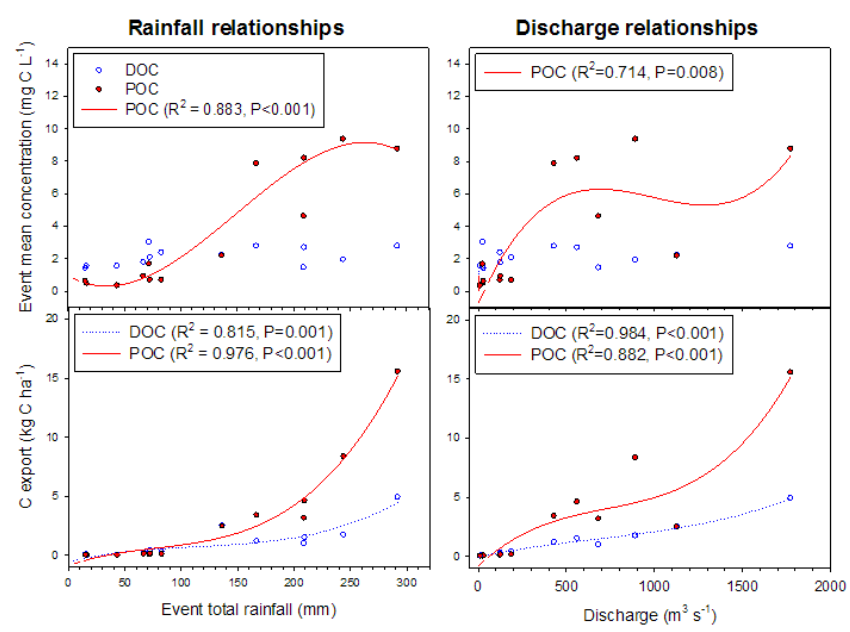

Figure 2. Relationships between measures of storm magnitude (event total rainfall or discharge) and the discharge-weighted event mean concentrations or the export of DOC and POC in the forest stream during 13 storm events. Best-fit regressions are indicated only if $P<0.05$.

- chloroform (CF), bromodichloromethane (BDCM), dibromochloromethane (DBCM), bromoform (BF), dichloroacetonitrile (DCAN), and 1.1-dichloro-2-propanone (DCP) were extracted according to EPA Method 501.2, and the extracts were analyzed by gas chromatography-mass spectrometry (7890A GC/5975C MS; Agilent Technologies, Inc., Santa Clara, USA) in the selected ion monitoring mode. Ions for quantitative determination of six DBPs were as follows CF and BDCM: $m / z=83,85$; DBCM: 127, 129; BF: 173, 254; DCAN: 74, 82; DCP: 43. Estimated method detection limits (MDL) were between 0.04 and $0.1 \mu \mathrm{g} \mathrm{L}^{-1}$. As the concentrations of DBCM, BF, DCAN, and DCP were below the MDLs for most samples, the combined concentrations of $\mathrm{CF}$ and $\mathrm{BDCM}$ are reported here as total trihalomethanes (TTHM).

Short-term changes in biodegradable DOC (BDOC) and optical properties of DOM and SS-DOM sampled from the second peak flow period of the same storm event in June 2011 were examined in a 30-day incubation experiment. Water samples were filtered through a $0.2 \mu \mathrm{m}$ membrane filter (cellulose acetate membrane filter, Whatman) to remove particulates and most of the microbial organisms, and then incubated in triplicates $(400 \mathrm{~mL}$ each) with an inoculum $(1 \%$ of the final volume) under controlled laboratory conditions at $25^{\circ} \mathrm{C}$ in the dark. The inoculum was prepared using a method modified from Fellman et al. (2009). Sediment samples collected from the streambank and bed were leached with an unfiltered stream-water sample from the same site. The leachates were filtered through a $2 \mu \mathrm{m}$ filter (Nuclepore polycarbonate filter, Whatman) to remove coarse particles $>2 \mu \mathrm{m}$. The filtrates containing microbial cells $(<2 \mu \mathrm{m})$ were then incubated at $25^{\circ} \mathrm{C}$ for 7 days before addition to the in- cubation samples. BDOC and optical properties were compared among three treatments: (1) DOM that already existed at the time of sampling (DOM treatment), (2) DOM added with freeze-dried SS samples collected at the same time as the DOM samples (DOM + SS treatment), and (3) ultrapure water added with freeze-dried SS samples (SS treatment). The three treatments were designed to evaluate biodegradation potentials of DOM and SS-associated POM components in isolation (DOM and SS treatments) and combined (DOM + SS treatment). The same inoculum (1\% of the final volume) was added to all samples. One hour after the addition of SS, a small portion of each sample was sampled and filtered through a $0.2 \mu \mathrm{m}$ membrane filter to measure the initial concentrations of DOC leached from the SS. Subsamples were collected from the incubation bottles and analyzed for DOC concentrations, UV absorbance at $254 \mathrm{~nm}\left(\mathrm{UVA}_{254}\right)$, and fluorescence excitation emission matrices (EEMs) on days $1,3,6,13,21$, and 30 of the incubation period.

Fluorescence EEMs of the filtered water samples were obtained by simultaneous scanning over excitation wavelengths from 200 to $400 \mathrm{~nm}$ at $5 \mathrm{~nm}$ steps and emission wavelengths from 290 to $540 \mathrm{~nm}$ at $1 \mathrm{~nm}$ steps using a fluorescence spectrophotometer (F7000, Hitachi, Tokyo, Japan). Scan speed was $2400 \mathrm{~nm} \mathrm{~min}^{-1}$ and the bandwidth was set to $5 \mathrm{~nm}$ for both excitation and emission. A $290 \mathrm{~nm}$ cutoff filter was used for all the measurements to minimize second order Rayleigh scattering. Blank runs were conducted with Ultrapure water for every batch of 10 samples. The Raman peak of water at excitation $350 \mathrm{~nm}$ emission $^{-1} 400 \mathrm{~nm}$ was used to assess the stability of the fluorescence spectrometer. To account partially for the Rayleigh scattering, the machine response to blank runs was subtracted from the EEMs of the samples. The inner-filter effect was corrected based on McKnight et al. (2001). To deconvolute the major fluorescent components, parallel factor analysis (PARAFAC) modeling was performed using MATLAB 7.0 (Mathworks, Natick, USA) with the DOM Fluor toolbox (http://www.models. life.ku.dk) based on a method developed by Stedmon and Bro (2008). Three PARAFAC components were identified and termed humic-, fulvic-, and protein-like fluorescent components based on the similarity of the peak wavelengths to values reported in the literature (Fellman et al., 2010).

\section{Results}

\subsection{The relationships between storm magnitude and $C$ export}

Significant relationships were found between measures of storm magnitude (total event rainfall and discharge) and discharge-weighted mean concentrations or exports of organic $\mathrm{C}$ in the forest stream during 13 storm events (Fig. 2). The event mean concentrations of DOC tended to increase linearly with increasing precipitation and discharge, but the 
relationships were not statistically significant $(P=0.15)$. In contrast, event mean concentrations of POC and exports of both DOC and POC had significant nonlinear relationships with event total rainfall or discharge. Cubic polynomial equations, which represented best-fit regressions for all these nonlinear relationships, better accounted for the variations of the observed nonlinear relationships than power law functions or second-order polynomial functions that had been used to describe discharge-DOC relationships in previous studies (e.g., Raymond and Saiers, 2010).

Across a range of small and moderate storm events with up to $100 \mathrm{~mm}$ of precipitation per event, the concentrations and fluxes of DOC and POC increased gradually with increasing precipitation or discharge, with higher values of DOC than POC for most events. However, above the threshold precipitation greater than $100 \mathrm{~mm}$ per event, POC concentrations and fluxes increased drastically, considerably exceeding the levels of DOC. Compared to the very strong relationships with rainfall, POC concentrations and fluxes exhibited weaker relationships with discharge. Below-average concentrations and fluxes of POC during a few storm events with substantial amount of antecedent precipitation (e.g., event 4; Table 1) resulted in large variations in POC concentration and export at similar ranges of discharge (Fig. 2).

\subsection{DBP formation of DOC and POC exported during extreme storm event}

We examined short-term dynamics of DOC and POC export and their implications for $\mathrm{C}$ biodegradation and DBP formation in the receiving headwater stream for two extreme storm events that were part of 13 events analyzed in Fig. 2 (Fig. 3). Responses of discharge and stream water chemistry differed between the two storm events. The second phase (total rainfall: $120 \mathrm{~mm}$; mean hourly rainfall: $2.1 \mathrm{~mm} \mathrm{~h}^{-1}$ ) of event 12, which started on 25 June 2011, exhibited greater rainfall amount and higher intensity than the preceding phase (total rainfall: $89 \mathrm{~mm}$; mean hourly rainfall: $1.5 \mathrm{~mm} \mathrm{~h}^{-1}$ ) that started on 22 June following a relatively dry pre-monsoon period in June. As the cumulative rainfall approached $200 \mathrm{~mm}$, discharge and turbidity (> 1000 NTU) increased drastically toward the peak flow of the second phase (Fig. 3). While DOC concentrations reached similar maximum levels (2-3 $\left.\mathrm{m} \mathrm{C} \mathrm{L}^{-1}\right)$ during all peak discharge periods, POC concentrations, along with TSS concentrations and turbidity, exhibited large increases during the short peak flow periods of the intense rainfalls.

During the first phase of event 12 , the concentrations of TTHM formed by DOM and SS-DOM changed in parallel with varying concentrations of DOC or POC, respectively (Fig. 4). The positive relationship between the concentrations of TTHM and DOC $\left(r^{2}=0.894 ; P=0.015\right)$ or POC $\left(r^{2}=0.739 ; P=0.062\right)$ in the water samples collected over the course of the first storm phase pointed to the importance of the amount of organic matter exposed to chlorination

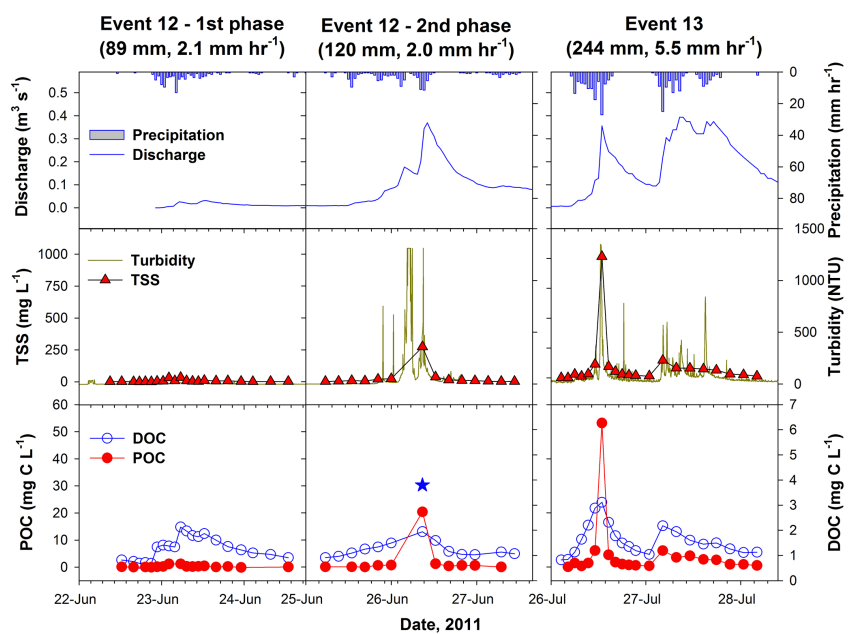

Figure 3. Temporal variations in hourly precipitation $\left(\mathrm{mm} \mathrm{h}^{-1}\right)$, discharge $\left(\mathrm{m}^{3} \mathrm{~s}^{-1}\right)$, turbidity (NTU), and the concentrations $\left(\mathrm{mg} \mathrm{L}^{-1}\right)$ of TSS, DOC, and POC in the forest stream during two extreme storm events in 2011. Concentrations of TSS, DOC, and POC were measured for water samples collected at 2-hour intervals. The star symbol above the peak concentrations of DOC and POC on 26 June indicates grab sampling conducted for the laboratory BDOC incubation experiment.

for accounting for temporal variations in TTHM formation. TTHM formation potentials differed substantially between $\operatorname{DOM}\left(14.2-26.7 \mu \mathrm{g} \mathrm{L}^{-1}\right)$ and SS-DOM (1.5-7.5 $\left.\mu \mathrm{g} \mathrm{L}^{-1}\right)$.

\subsection{Biodegradation of DOC and POC exported during extreme storm event}

DOM and SS-DOM from the water samples collected during the second storm peak of event 12 (sampling time indicated as "BDOC sample" in Figs. 3, 4) exhibited relatively small changes in DOC concentrations over the 30-day incubation (Fig. 5). DOC concentrations decreased in the DOM by $7.1 \%$ and in the DOM + SS by $6.6 \%$, but increased in the SS treatment by $12.9 \%$ relative to the initial DOC concentrations (Fig. 5; Table 2). BDOC concentrations in the DOM and $\mathrm{DOM}+\mathrm{SS}$ treatments were similar to each other and also over 7 and 30 days (Table 2). Although the absolute magnitude of BDOC was much smaller in the SS treatment than in the other treatments, BDOC percentage values relative to the initial DOC concentrations were comparable to those for other treatments during the first half of the incubation and exhibited a shift from the initial rapid decreases (decrease of $10.6 \%$ over 7 days) to the gradual increases during the following period, resulting in an overall increase of $12.9 \%$ over 30 days (Table 2).

Continuous transformations of OM between the dissolved and particulate phase were also indicated by the SS samples exhibiting significantly greater changes in both specific UV absorbance at $254 \mathrm{~nm}\left(\mathrm{SUVA}_{254}\right)$ and specific fluorescence intensities of three PARAFAC components per unit mass of 
Table 1. Characteristics of 13 monsoon rainfall events. Original data of DOC and POC concentrations from eight events that were published elsewhere (references provided as notes) are here used to calculate discharge-weighted event mean concentrations and fluxes in Fig. 2. The events 12 and 13 were examined in detail to evaluate potentials of DOC and POC for DBP formation and biodegradation (Figs. 3-5).

\begin{tabular}{|c|c|c|c|c|c|c|}
\hline Event & Start time & $\begin{array}{r}\text { Duration } \\
\text { (h) }\end{array}$ & $\begin{array}{r}\text { Total rainfall } \\
(\mathrm{mm})\end{array}$ & $\begin{array}{r}\text { Mean rainfall } \\
\text { intensity }\left(\mathrm{mm} \mathrm{h}^{-1}\right)\end{array}$ & $\begin{array}{r}\text { 7-d antecedent } \\
\text { rainfall }(\mathrm{mm})\end{array}$ & Note \\
\hline 1 & 18-06-2008 03:00 & 19 & 72 & 3.8 & 0 & Jung et al. 2012 \\
\hline 2 & $16-07-2008$ 13:00 & 6 & 17 & 2.8 & 40 & Jung et al. 2012 \\
\hline 3 & 24-07-2008 02:00 & 33 & 292 & 8.9 & 86 & Jung et al. 2012 \\
\hline 4 & 26-07-2008 04:00 & 26 & 137 & 5.3 & 378 & Jung et al. 2012 \\
\hline 5 & 20-06-2009 06:00 & 11 & 15 & 1.4 & 55 & \\
\hline 6 & 09-07-2009 05:00 & 14 & 167 & 11.9 & 14 & \\
\hline 7 & 18-07-2009 00:00 & 36 & 73 & 2.0 & 298 & \\
\hline 8 & 11-08-2009 14:00 & 23 & 210 & 9.1 & 6 & Jeong et al. 2012 \\
\hline 9 & 02-07-2010 03:00 & 31 & 44 & 1.4 & 10 & Jeong et al. 2012 \\
\hline 10 & $16-07-201016: 00$ & 51 & 83 & 1.6 & 7 & Jeong et al. 2012 \\
\hline 11 & 02-09-2010 00:00 & 41 & 67 & 1.6 & 45 & Jeong et al. 2012 \\
\hline 12 & $22-06-201122: 00$ & 93 & 209 & 2.1 & 0 & Figs. 3-5 \\
\hline 13 & 26-07-2011 18:00 & 44 & 244 & 5.5 & 9 & Fig. 3. \\
\hline
\end{tabular}

DOC compared with the DOM samples (Fig. 5; Table 2). $\mathrm{SUVA}_{254}$ in the SS-DOM was initially lower than in the other treatments, but exceeded the levels of the other treatments during the second half of the incubation, whereas the specific fluorescence intensities of three PARAFAC components were highest in the SS samples throughout most of the incubation period (Fig. 5). For all treatments in general and the treatments containing SS in particular, the intensities of SUVA 254 and the humic- and fulvic-like fluorescence increased continuously with time, whereas the intensities of protein-like fluorescence continued to decrease during the course of the incubation, resulting in striking differences in the intensity over the entire incubation between the proteinlike fluorescence and other optical measurements (Table 2).

\section{Discussion}

\subsection{Importance of extreme rainfall events for DOC and POC export}

Comparison of DOC and POC exports during 13 monsoon rainfall events of various magnitude and duration well illustrates differential storm responses of DOC and POC (Figs. 2, 3). Although both DOC and POC exports increased with increasing rainfall and discharge, much stronger responses of POC to intense rainfalls suggested the disproportionate importance of a few extreme rainfall events as a shortcut of organic $\mathrm{C}$ export to mountainous headwater streams. During the 1-year period (17 July 2009-16 July 2010) for which the annual $\mathrm{C}$ export from the same study watershed was estimated using continuous in situ measurements, one short extreme storm event with a cumulative rainfall of $210 \mathrm{~mm}$ comprised a disproportionately large proportion of the annual export of DOC $\left(23 \%\right.$ of $\left.3.2 \mathrm{~kg} \mathrm{Cha}^{-1} \mathrm{yr}^{-1}\right)$ and
POC (62\% of $3.7 \mathrm{~kg} \mathrm{Cha}^{-1} \mathrm{yr}^{-1}$ ) (Jeong et al., 2012). In the current synthesis of 13 storm events (Fig. 2), the export of DOC and POC during each of the four storm events with cumulative precipitation exceeding $200 \mathrm{~mm}(209-292 \mathrm{~mm})$ ranged from $0.99-4.91$ and $3.15-15.55 \mathrm{~kg} \mathrm{Cha}^{-1}$, respectively. In particular, the large variations of POC export across these storm events suggest that a few extreme events can account for a substantial portion or even exceed the annual $\mathrm{C}$ export observed for relatively dry years such as the year reported by Jeong et al. (2012).

The importance of extreme events for DOC export has been investigated recently by synthesizing regional monitoring data sets (Raymond and Saiers, 2010) or by highfrequency sampling during extreme hydrologic events such as hurricanes (Yoon and Raymond, 2012). In a metadata analysis using DOC monitoring data covering 30 small eastern US forested watersheds, Raymond and Saiers (2010) found a nonlinear relationship between the annual export of DOC and annual stream discharge, which was described by a second-order polynomial function similar to the relationships found in this study. A high-frequency storm event sampling in a forested watershed in Esopus Creek, New York State during Hurricane Irene (total precipitation of $293 \mathrm{~mm}$ for 27-29 August 2011) showed that the export of DOC during this 200 -year event accounted for $43 \%$ of the average annual DOC export (Yoon and Raymond, 2012).

Stream exports of DOC and POC have been compared in diverse types of watersheds under different rainfall regimes (Fisher and Likens, 1973; Bilby and Likens, 1979; Wallace et al., 1995; Coynel et al., 2005). However, only a few studies have provided high-frequency time series data of POC that also encompass extreme storm events (Kim et al., 2010; Jeong et al., 2012; Dhillon and Inamdar, 2013). It has been suggested that large storm-induced exports of POC 


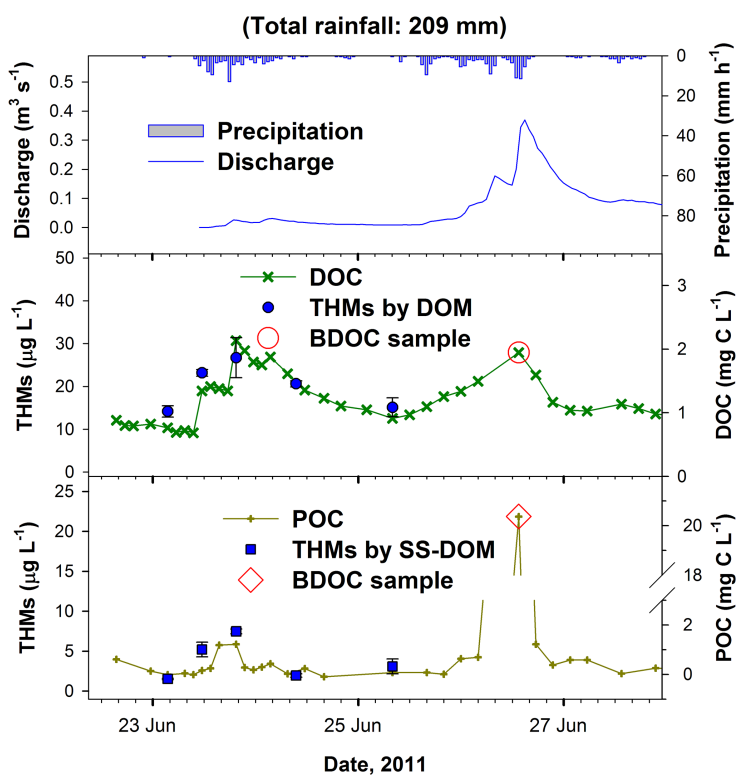

Figure 4. Temporal changes in the concentrations $\left(\mathrm{mg} \mathrm{CL}^{-1}\right)$ of DOC and POC, and the potentials ( $\left.\mu \mathrm{g} \mathrm{L}^{-1}\right)$ of TTHM formation by either DOM or suspended sediment-derived DOM (SS-DOM) over the course of the first storm event in 2011. Error bars indicate \pm one standard error $(n=3)$. BDOC sample refers to the samples of DOC or POC collected for the biodegradation incubation experiment (Fig. 5).

are characteristic of erosion-prone mountainous watersheds, particularly in response to intense storm events (Jung et al., 2012). However, large storm pulses of POC can also occur in forested watersheds located on relatively gentle slopes, when extreme hydrologic events such as tropical storms increase the vulnerability of stream banks and soils on steep slopes to soil erosion (Dhillon and Inamdar, 2013). Dhillon and Inamdar (2013) observed large disparities between DOC and POC exported from a forest watershed in Maryland during extreme rainfall events accompanying Hurricane Irene. Our results of large storm pulses of POC exceeding the rather moderate increases of DOC (Figs. 2, 3) also suggest that the stream $\mathrm{C}$ export regime would shift toward a greater dominance of POC over DOC, if watersheds were subjected to larger and more extreme storm events.

Relatively small variations in the peak DOC concentrations between the two periods of event 12 (Fig. 3), together with small increases of DOC concentrations and fluxes with increasing rainfall and discharge (Fig. 2), might imply a limited range of DOC supply from the major sources in the upper soil horizons (Hornberger et al., 1994; Inamdar et al., 2004). In contrast, POC export might have increased in a nonlinear relationship with increasing cumulative precipitation after passing a threshold precipitation during short peak flow periods of intense storm events. Nonlinear increases in POC export above a threshold precipitation have been ascribed to a certain level of energy required to initiate soil ero-
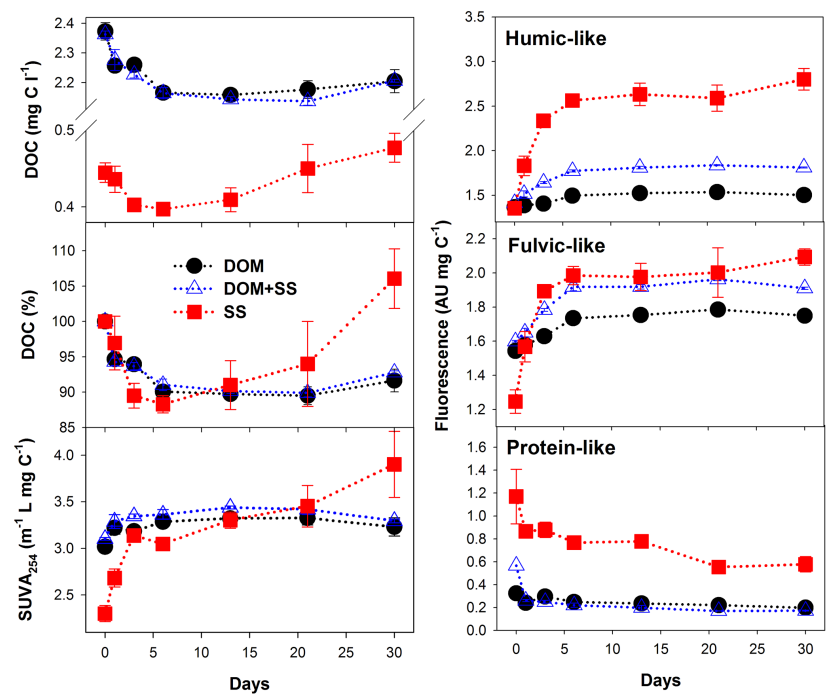

Figure 5. Temporal changes in DOC concentrations $\left(\mathrm{mg} \mathrm{C} \mathrm{L}^{-1}\right.$ or $\%$ of the initial concentration), $\mathrm{SUVA}_{254}\left(\mathrm{~L} \mathrm{mg} \mathrm{C}^{-1} \mathrm{~m}^{-1}\right)$, and specific fluorescence (AU mg ${ }^{-1}$ DOC) of three PARAFAC components (C1: humic-like fluorescence; C2: fulvic-like fluorescence; C3: protein-like fluorescence) during the 30-day incubation of DOM (filtered stream water), DOM + SS (filtered stream water added with suspended sediment), and SS (ultrapure water added with suspended sediment) samples. Error bars indicate \pm one standard error $(n=3)$.

sion at sources such as streambed, streambank, and bare soil surfaces on steep slopes (Jeong et al., 2012; Dhillon and Inamdar, 2013). POC concentrations and export also exhibited threshold relationships with discharge (Fig. 2). Larger variations of POC concentrations and export at similar levels of discharge suggest that discharge-POC relationships depend on antecedent rainfalls more strongly than rainfall-POC relationships. Reduced export of DOC and POC during falling hydrograph events have been ascribed to temporary depletion of terrestrial supply of source materials or shifts in the timing of runoff contributions from major source areas (Raymond and Saiers, 2010; Jeong et al., 2012).

\subsection{Storm-enhanced DBP formation potentials of DOC and POC}

Although potentials of SS-DOM for trihalomethane (THM) formation were measured for only a small number of samples due to difficulties associated with collecting large-volume samples under harsh storm sampling conditions, simultaneous measurements of DOC and POC for THM formation potentials provide rare empirical evidence for the rapid transformation of potentially soluble components of particulate organic matter (POM) into DOM moieties that can actively participate in chlorination reactions. The positive relationship between POC concentrations and TTHM formation potentials during the first phase of event 12 suggests that large 
Table 2. Changes in DOC concentrations $\left(\mathrm{mg} \mathrm{CL}^{-1}\right)$ over 7 and 30 days and $\mathrm{SUVA}_{254}\left(\mathrm{~L} \mathrm{mg} \mathrm{C}^{-1} \mathrm{~m}^{-1}\right)$ and specific fluorescence $(\mathrm{AU} \mathrm{mg} \mathrm{C}-1)$ over 30 days of incubation.

\begin{tabular}{|c|c|c|c|c|c|c|c|c|c|}
\hline \multirow[t]{2}{*}{ Sample } & \multirow{2}{*}{$\begin{array}{l}\text { Initial DOC } \\
\left(\mathrm{mg} \mathrm{C} \mathrm{L}^{-1}\right)\end{array}$} & \multicolumn{2}{|c|}{$\operatorname{BDOC}(7 \mathrm{~d})$} & \multicolumn{2}{|c|}{ BDOC (30d) } & \multirow{2}{*}{$\begin{array}{l}\mathrm{SUVA}_{254}(30 \mathrm{~d}) \\
\left(\mathrm{L} \mathrm{mg} \mathrm{C}^{-1} \mathrm{~m}^{-1}\right)\end{array}$} & \multicolumn{3}{|c|}{$\begin{array}{l}\text { Specific fluorescence (30 d) } \\
\qquad\left(\mathrm{AU} \mathrm{mg} \mathrm{C}^{-1}\right)\end{array}$} \\
\hline & & $\left(\mathrm{mg} \mathrm{CL}^{-1}\right)$ & $(\%)$ & $\left(\mathrm{mg} \mathrm{CL}^{-1}\right)$ & $(\%)$ & & $\mathrm{C} 1$ & $\mathrm{C} 2$ & $\mathrm{C} 3$ \\
\hline DOM & $\begin{array}{r}2.37^{\mathrm{a}} \\
(0.03)\end{array}$ & $\begin{array}{l}0.21^{\mathrm{a}} \\
(0.02)\end{array}$ & $\begin{array}{r}8.67 \\
(0.67)\end{array}$ & $\begin{array}{r}0.17^{\mathrm{a}} \\
(0.02)\end{array}$ & $\begin{array}{l}7.09^{\mathrm{a}} \\
(0.93)\end{array}$ & $\begin{array}{r}-0.21^{\mathrm{a}} \\
(0.04)\end{array}$ & $\begin{array}{r}-0.14^{\mathrm{a}} \\
(0.02)\end{array}$ & $\begin{array}{r}-0.21^{\mathrm{a}} \\
(0.02)\end{array}$ & $\begin{array}{r}0.13 \\
(0.03)\end{array}$ \\
\hline $\mathrm{DOM}+\mathrm{SS}$ & $\begin{array}{r}2.36^{\mathrm{a}} \\
(0.01)\end{array}$ & $\begin{array}{r}0.20^{\mathrm{a}} \\
(0.03)\end{array}$ & $\begin{array}{r}8.37 \\
(1.24)\end{array}$ & $\begin{array}{r}0.16^{\mathrm{a}} \\
(0.01)\end{array}$ & $\begin{array}{r}6.61^{\mathrm{a}} \\
(0.33)\end{array}$ & $\begin{array}{r}-0.19^{\mathrm{a}} \\
(0.02)\end{array}$ & $\begin{array}{r}-0.40^{\mathrm{a}} \\
(0.01)\end{array}$ & $\begin{array}{r}-0.31^{\mathrm{a}} \\
(0.00)\end{array}$ & $\begin{array}{l}- \\
-\end{array}$ \\
\hline SS & $\begin{array}{l}0.44^{\mathrm{b}} \\
(0.01)\end{array}$ & $\begin{array}{l}0.05^{\mathrm{b}} \\
(0.01)\end{array}$ & $\begin{array}{l}10.55 \\
(2.63)\end{array}$ & $\begin{array}{r}-0.06^{\mathrm{b}} \\
(0.01)\end{array}$ & $\begin{array}{r}-12.86^{\mathrm{b}} \\
(0.95)\end{array}$ & $\begin{array}{r}-1.60^{\mathrm{b}} \\
(0.28)\end{array}$ & $\begin{array}{r}-1.45^{\mathrm{b}} \\
(0.17)\end{array}$ & $\begin{array}{r}-0.85^{\mathrm{b}} \\
(0.12)\end{array}$ & $\begin{array}{r}0.59 \\
(0.23)\end{array}$ \\
\hline
\end{tabular}

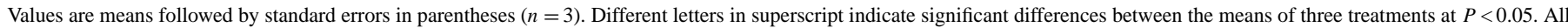
values were calculated as

the initial minus the final value, so positive and negative values indicate decreases and increases relative to the initial values, respectively. BDOC was also calculated as $\%$ of the initial DOC concentration. $\mathrm{C} 1, \mathrm{C} 2$, and $\mathrm{C} 3$ indicate humic-like, fulvic-like, and protein-like PARAFAC components, respectively.

increases in POC concentrations during intense storm events, as observed during the second phase of the same storm event and the following event 13 (Fig. 3), could result in much higher levels of THMs than observed during the relatively moderate initial storm phase. DBP formation potentials have been correlated with the concentrations of DOC as the primary precursor of DBPs (Chow et al., 2007; Kraus et al., 2008; Nguyen et al., 2013). However, there has been no attempt to measure potentials of DBP formation in unfiltered stream water that might contain labile components leached from SS.

Storm-induced increases in DOC input to drinking water source waters have been suggested as a potential threat to the performance of treatment processes in drinking water facilities (Hurst et al., 2004). Although a few studies have linked the storm pulses of DOC with increasing potentials of DBP formation (Chow et al., 2007; Kraus et al., 2008; Nguyen et al., 2013), there have been rare systematic approaches to examine the chemical reactivity and biological transformation of both DOM and POM exported under storm flow conditions. Our findings of rapid dissolution of soluble organic components from SS and the subsequent responses to biological degradation and chlorination emphasize the hitherto neglected reactivity of POM and its implications for both aquatic $\mathrm{C}$ dynamics and public health concerns in the drinking water sector. Pulsed export of POC during intense storm events, as shown in Fig. 3, might contain a higher proportion of old humic materials that are usually enriched in ${ }^{13} \mathrm{C}$ than found at base or low flow (Jung et al., 2012). Humic materials in excess of the usual coagulant dose can drastically decrease the removal of particulate turbidity due to preferential formation of complexes between humic complexation sites and coagulant metals (Hurst et al., 2004). Based on the strong positive correlations between DBP formation potentials and optical measurements of DOM (UVA 254 and fluorescence EEM peaks related to humic substances) in a forested watershed in Korea during two storm events, Nguyen et al. (2013) argued that humic-like DOM components with more aromatic and condensed structures have a higher potential to form DBPs upon chlorination than other DOM moieties.

\subsection{Storm pulses of DOC and POC as sources of labile $C$ in headwater stream}

Unlike previous studies that focused on microbial transformation of labile DOM components, our results provide rare insights into microbial alterations of the optical properties of particle-derived DOM. Previous BDOC experiments that focused on DOM did not consider the rapid conversion of OM between the dissolved and particulate phase in streams and rivers. The exclusion of SS can lead to a significant underestimation of DOM biodegradation and changes in optical properties, considering the role of SS surfaces as biofilm that can enhance the attachment and growth of microbes (Garnier et al., 2008). In our study, the actual rate of biodegradation of POC is not known, because we did not measure changes in POC concentrations or $\mathrm{CO}_{2}$ evolution as a measure of POC biodegradation. Given the unusually high concentrations of POC during peak flow periods of intense or extreme storm events (Figs. 2, 3) and the fact that storm pulses of POC can contain a large pool of potentially soluble or biodegradable $\mathrm{OM}$, the actual biodegradation of POC might be much higher than estimated from the small BDOC values observed for the SS samples.

Only a few studies have directly compared the biodegradation of DOM and POM (del Giorgio and Pace, 2008; Garnier et al., 2008). In the turbidity maximum zone of the Seine Estuary, France, Garnier et al. (2008) found much higher rates of biodegradation for POC (the change in POC concentration between the start and end of 45-day incubation) than for DOC. In a study comparing BDOC and bacterial respiration of DOC along the Hudson River, del Giorgio and Pace (2008) also found a significant contribution of POC to the riverine bacterial respiration of DOC and suggested that POC might affect bacteria not through direct consumption of POC but 
by inputs of labile components to the DOC pool. In a 14day incubation experiment with water-soluble OM extracted from leaf litter, Hur et al. (2009) found that microbial transformations of labile OM increased $\mathrm{SUVA}_{254}$ and fulvic- and humic-like fluorescence, but decreased protein-like fluorescence intensities. As suggested by Hur et al. (2009), soluble components of POM that have simple structures can be degraded preferentially by decomposers and hence enhance microbial activity, increasing the production of dissolved humic materials as byproducts.

The BDOC percentage values observed in this study fall within the low range of the BDOC values reported for various forested headwater streams (Servais et al., 1987: 11\%; Fellman et al., 2009: 20-23\%; Kang and Mitchell, 2013: 6-18\%). The almost overlapping temporal patterns of DOC concentrations, observed in both the DOM and $\mathrm{DOM}+\mathrm{SS}$ treatments, might imply an absence of the influence of SS on DOM biodegradation. However, the continuous increases in DOC concentration following the initial decreases over the first 7 days in the SS treatment (Fig. 5), along with increasingly higher humic- and fulvic-like fluorescence of DOM + SS samples as compared with the DOM values (Fig. 5; Table 2), suggest that the DOC pool, reduced by the biodegradation of labile organic components in the $\mathrm{DOM}+\mathrm{SS}$ treatment, might have been replenished concurrently by the continuous supply of DOC from potentially soluble OM pools in the SS, resulting in no apparent differences in DOC concentrations with slight modifications of DOM optical properties. The increasing DOC concentrations following the initial decreases in the SS treatment can be explained by the shifting balance between the consumption and production of DOC towards an increased dissolution of relatively recalcitrant organic components during the later phase compared with the initial, rapid biodegradation of labile OM dissolved from the fresh SS.

\section{Conclusions}

Repeated high-frequency storm event samplings at 2-hour intervals allowed for a systematic comparison of DOC and POC export in the mountainous headwater stream during 13 storm events over 4 years. The results show that POC export increases nonlinearly above the thresholds of precipitation and discharge, significantly exceeding the relatively small increases of DOC. Very large magnitudes and variations of the storm-induced export of organic $\mathrm{C}$ in general, and POC in particular, imply that the export of POC during a few extreme storm events can comprise a significant portion or the bulk of the annual soil $\mathrm{C}$ loss and that storm pulses of POC can become increasingly important as a pathway of soil $\mathrm{C}$ loss in mountainous watersheds under monsoon climates, in response to more frequent occurrence of extreme rainfall events, as predicted for a large part of the Northern Hemisphere including the study region as a con- sequence of global climate change (Choi et al., 2008; Min et al., 2011). Results from a single study site cannot be extrapolated to estimate $\mathrm{C}$ mobilization from terrestrial sources at the regional or global scale. However, this study provides rare high-frequency monitoring data to reinforce the growing recognition that the export of terrigenous organic $\mathrm{C}$ might be much greater than currently estimated, if we take into consideration the missing $\mathrm{C}$ that cannot be captured with lowfrequency sampling schemes.

This study also demonstrates that storm pulses of POC contain labile moieties that can dissolve rapidly in stream water and become exposed to microbial transformations, as revealed by the greater changes in $\mathrm{SUVA}_{254}$ and specific fluorescence intensities of SS-DOM compared with DOM. While current debates on erosion-enhanced sinks of atmospheric $\mathrm{CO}_{2}$ have focused on reduced decomposition of eroded $\mathrm{C}$ under depositional settings (Van Oost et al., 2007; Lal and Pimentel, 2008), recent findings of high biodegradation potentials of POC in large temperate and tropical rivers (Etcheber et al., 2007; del Giorgio and Pace, 2008; Ward et al., 2013) raise an important question as to whether eroded $\mathrm{C}$ degrades faster after entering streams and rivers than in source soils. Our measurements of BDOC and optical properties of SS-DOM in the headwater stream suggest that rapid conversion of labile OM between the DOC and POC pools starts to occur even in upstream source areas of mountainous river systems in monsoon Asia, which have been suggested to transport organic $\mathrm{C}$ without significant chemical transformations (Galy et al., 2007; Goldsmith et al., 2008). Future study of $\mathrm{C}$ transformations and storage in inland waters should incorporate POC transformations to improve predictions of $\mathrm{C}$ transport through inland waters under changing rainfall regimes. The new finding of increasing potentials of THM formation with rising POC concentrations during intense storms also underscores the importance of monitoring POC as well as DOC for watershed-level climate change adaptation plans, which might involve monitoring drinking water sources in response to the increasing frequency and intensity of storm events across many parts of the world.

Acknowledgements. This work was supported by the National Research Foundation of Korea funded by the Ministry of Education, Science and Technology (Basic Science Research Program 2014R1A2A2A01006577; ERC 2009-0083527). Special thanks go to Jin Hur for his help with PARAFAC modeling. We also thank Kyeong-Won Jo, Hyn-Ju Lee, Jong-Jin Jeong, Min-Ji Park, Bo-Bae Park, and Jae-Seon Chae for their help with sampling and analyses.

Edited by: M. Bahn 


\section{References}

Aufdenkampe, A. K., Mayorga, E., Raymond, P. A., Melack, J. M., Doney, S. C., Alin, S. R., Aalto, R. E., and Yoo, K.: Riverine coupling of biogeochemical cycles between land, oceans, and atmosphere, Front. Ecol. Environ., 9, 53-60, 2011.

Bastviken, D, L., Tranvik, J., Downing, J. A., Crill, P. M., and Enrich-Prast, A.: Freshwater methane emissions offset the continental carbon sink, Science, 331, 50, 2011.

Battin, T. J., Kaplan, L. A., Findlay, S., Hopkinson, C. S., Marti, E., Packman, A. I., Newbold, J. D., and Sabater, F.: Biophysical controls on organic carbon fluxes in fluvial networks, Nat. Geosci., 1, 95-100, 2008.

Battin, T. J., Luyssaert, S., Kaplan, L. A., Aufdenkampe, A. K., Richter, A., and Tranvik, L. J.: The boundless carbon cycle, Nat. Geosci., 2, 598-600, 2009.

Beggs, K. H. M., Summers, R. S., and McKnight, D. M.: Characterizing chlorine oxidation of dissolved organic matter and disinfection by-product formation with fluorescence spectroscopy and parallel factor analysis, J. Geophys. Res., 114, G04001, doi:10.1029/2009JG001009, 2009.

Bilby, R. E. and Likens, G. E.: Effect of hydrologic fluctuations on the transport of fine particulate organic carbon in a small stream, Limnol. Oceanogr., 24, 69-75, 1979.

Choi, G., Collins, D., Ren, G., Trewin, B., Baldi, M., Fukuda, Y., Afzaal, M., Pianmana, T., Gomboluudev, P., Huong, P. T. T. H., Lias, N., Kwon, W. T., Boo, K. O., Cha, Y. M., and Zhou, Y.: Changes in means and extreme events of temperature and precipitation in the Asia-Pacific Network region, 1955-2007, Int. J. Climatol., 29, 1906-1925, 2009.

Choi, K., Kwon, W. T., Boo, K. O., and Cha, Y. M.: Recent spatial and temporal changes in means and extreme events of temperature and precipitation across the Republic of Korea, J. Korean Geogr. Soc., 43, 681-700, 2008.

Chow, A. T., Dahlgren, R. A., and Harrison, J. A.: Watershed sources of disinfection byproduct precursors in the Sacramento and San Joaquin Rivers, California, Environ. Sci. Technol., 41, 7645-7652, 2007.

Cole, J. J., Prairie, Y. T., Caraco, N. F., McDowell, W. H., Tranvik, L. J., Striegl, R. G., Duarte, C. M., Kortelainen, P., Downing, J. A., Middelburg, J. J., and Melack, J.: Plumbing the global carbon cycle: Integrating inland waters into the terrestrial carbon budget, Ecosystems, 10, 171-184, 2007.

Coynel, A., Etcheber, H., Abril, G., Maneux, E., Dumas, J., and Hurtrez, J. E.: Contribution of small mountainous rivers to particulate organic carbon input in the Bay of Biscay, Biogeochemistry, 74, 151-171, 2005.

Del Giorgio, P. A. and Davis, J.: Patterns in dissolved organic matter lability and consumption across aquatic ecosystems, in: Aquatic Ecosystems - Interactivity of Dissolved Organic Matter, edited by: Findlay, S. E. G. and Sinsabaugh, R. L., Academic Press, San Diego, 399-425, 2003.

Del Giorgio, P. A. and Pace, M. L.: Relative independence of dissolved organic carbon transport and processing in a large temperate river: The Hudson River as both pipe and reactor, Limnol. Oceanogr., 53, 185-197, 2008.

Dhillon, G. S. and Inamdar, S.: Extreme storms and changes in particulate and dissolved organic carbon in runoff: Entering uncharted waters?, Geophys. Res. Lett., 40, 1322-1327, 2013.
Etcheber, H., Taillez, A., Aril, G., Garnier, J., Servais, P., Moatar, F., and Commarieu, M.-V.: Particulate organic carbon in the estuarine turbidity maxima of the Gironde, Loire and Seine estuaries: origin and lability, Hydrobiologia, 588, 245-259, 2007.

Fellman, J. B., Hood, E., Amore D. V. D., Edwards, R. T., and White, D.: Seasonal changes in the chemical quality and biodegradability of dissolved organic matter exported from soils to streams in coastal temperate rainforest watersheds, Biogeochemistry, 95, 277-293, 2009.

Fellman, J. B., Hood, E., and Spencer, R. G. M.: Fluorescence spectroscopy opens new windows into dissolved organic matter dynamics in freshwater ecosystems: A review, Limnol. Oceanogr., 55, 2452-2462, 2010.

Fisher, S. G. and Likens, G. E.: Energy flow in Bear Brook, New Hampshire: an integrative approach to stream ecosystem metabolism, Ecol. Monogr., 43, 421-439, 1973.

Garnier, J., Billen, G., Even, S., Etcheber, H., and Servais, P.: Organic matter dynamics and budgets in the turbidity maximum zone of the Seine Estuary France, Estuar. Coast. Shelf. S., 77, 150-162, 2008.

Galy, V., France-Lanord, C., Beyssac, O., Faure, P., Kudrass, H., and Palhol, F.: Efficient organic carbon burial in the Bengal fan sustained by the Himalayan erosional system, Nature, 450, 407-410, 2007.

Goldsmith, S. T., Carey, A. E., Lyons, W. B., Kao, S. J., Lee, T. Y., and Chen, J.: Extreme storm events, landscape denudation, and carbon sequestration: Typhoon Mindulle, Choshui River, Taiwan, Geology, 36, 483-486, 2008.

Hornberger, G. M., Bencala, K. E., and McKnight, D. M.: Hydrological controls on dissolved organic carbon during snowmelt in the Snake River near Montezuma, Colorado, Biogeochemistry, 25, 147-165, 1994.

Hur, J., Park, M.-H., and Schlautman, M. A.: Microbial transformation of dissolved leaf litter organic matter and its effects on selected organic matter operational descriptors, Environ. Sci. Technol., 43, 2315-2321, 2009.

Hurst, A. M., Edwards, M. J., Chipps, M., Jefferson, B., and Parsons, S. A.: The impact of rainstorm events on coagulation and clarifier performance in potable water treatment, Sci. Total Environ., 321, 219-230, 2004.

Inamdar, S. P., Christopher, S. F., and Mitchell, M. J.: Export mechanisms for dissolved organic carbon and nitrate during summer storm events in a glaciated forested catchment in New York, USA, Hydrol. Process., 18, 2651-2661, 2004.

Jeong, J.-J.: Hydrologic Controls on the Export of Dissolved and Particulate Organic Carbon in a Forest Stream Investigated by High-Frequency In-Situ Monitoring, MS Thesis, Kangwon National University, Chuncheon, South Korea, 2011.

Jeong, J.-J., Bartsch, S., Fleckenstein, J., Matzner, E., Tenhunen, J., Lee, S. D., Park, S. K., and Park, J.-H.: Differential storm responses of dissolved and particulate organic carbon in a mountainous headwater stream, investigated by high-frequency in situ optical measurements, J. Geophys. Res., 117, G03013, doi:10.1029/2012JG001999, 2012.

Jung, B.-J., Lee, H.-J., Jeong, J.-J., Owen, J. S., Kim, B., Meusburger, K., Alewell, C., Gebauer, G., Shope, C., and Park, J.-H.: Storm pulses and varying sources of hydrologic carbon export from a mountainous watershed, J. Hydrol., 440-441, 90-101, 2012. 
Kang, P.-K. and Mitchell, M. J.: Bioavailability and size-fraction of dissolved organic carbon, nitrogen, and sulfur at the Arbutus Lake watershed, Adirondack Mountains, NY, Biogeochemistry, 115, 213-234, 2013.

Kim, S. J., Kim, J., and Kim, K.: Organic carbon efflux from a deciduous forest catchment in Korea, Biogeosciences, 7, 1323-1334, doi:10.5194/bg-7-1323-2010, 2010.

Kraus, T. E. C., Bergamaschi, B. A., Hernes, P. J., Spencer, R. G. M., Stepanauskas, R., Kendall, C., Losee, R. F., and Fujii, R.: Assessing the contribution of wetlands and subsided islands to dissolved organic matter and disinfection byproduct precursors in the Sacramento-San Joaquin River Delta: a geochemical approach, Org. Geochem., 39, 1302-1318, 2008.

Lal, R. and Pimentel, D.: Soil erosion: A carbon sink or source? Science, 319, 1040-1042, 2008.

Lim, K. J., Engel, B. A., Tang, Z., Choi, J., Kim, K. S., Muthukrishnan, S., and Tripathy, D.: Automated web GIS-based hydrograph analysis tool, WHAT, J. Am. Water Res. Assoc., 41, 1407-1416, 2005.

Mayorga, E., Aufdenkampe, A. K., Masiello, C. A., Krusche, A. V., Hedges, J. I., Quay, P. D., Richey, J. E., and Brown, T. A.: Young organic matter as a source of carbon dioxide outgassing from Amazonian rivers, Nature, 436, 538-541, 2005.

McKnight, D. M., Boyer, E. W., Westerhoff, P. K., Doran, P. T., Kulbe, T., and Andersen, D. T.: Spectrofluorometric characterization of dissolved organic matter for indication of precursor organic material and aromaticity, Limnol. Oceanogr, 46, 38-48, 2001.

Meybeck, M.: Carbon, nitrogen, and phosphorus transport by world rivers, Am. J. Sci., 282, 401-450, 1982.

Min, S.-K., Zhang, X., Zwiers, F. W., and Hegerl, G. C.: Human contribution to more-intense precipitation extremes, Nature, 470, 378-381, 2011.

Nguyen, H. V.-M., Lee, M.-H., Hur, J., and Schlautman, M. A.: Variations in spectroscopic characteristics and disinfection byproduct formation potentials of dissolved organic matter for two contrasting storm events, J. Hydrol., 481, 132-142, 2013.

Park, J.-H., Duan, L., Kim, B., Mitchell, M. J., and Shibata, H.: Potential effects of climate change and variability on watershed biogeochemical processes and water quality in Northeast Asia, Environ. Int., 36, 212-225, 2010.

Raymond, P. A. and Saiers, J. E.: Event controlled DOC export from forested watersheds, Biogeochemistry, 100, 197-209, 2010.

Raymond, P. A., Hartmann, J., Lauerwald, R., Sobek, S., McDonald, C., Hoover, M., Butman, D., Striegl, R., Mayorga, E., Humborg, C., Kortelainen, P., Dürr, H., Meybeck, M., Ciais, P., and Guth, P.: Global carbon dioxide emissions from inland waters, Nature, 503, 355-359, 2013.
Riggsbee, J. A., Orr, C. H., Leech, D. M., and Doyle, M. W.: Suspended sediments in river ecosystems: Photochemical sources of dissolved organic carbon, dissolved organic nitrogen, and adsorptive removal of dissolved iron, J. Geophys. Res., 113, doi:10.1029/2007JG000654, G03019, 2008.

Rook, J. J.: Chlorination reactions of fulvic acids in natural waters, Environ. Sci. Technol., 11, 478-482, 1977.

Servais, P, Billen, G., and Hascoët, M.-C.: Determination of the biodegradable fraction of dissolved organic matter in waters, Water Res., 21, 445-450, 1987.

Stallard, R. F.: Terrestrial sedimentation and the carbon cycle: Coupling weathering and erosion to carbon burial, Global Biogeochem. Cy., 12, 231-257, 1998.

Stedmon, C. A. and Bro, R.: Characterizing dissolved organic matter fluorescence with parallel factor analysis: a tutorial, Limnol. Oceanogr. Meth., 6, 572-579, 2008.

Syvitski, J. P. M., Vörösmarty, C. J., Kettner, A. J., and Green, P.: Impacts of humans on the flux of terrestrial sediment to the global coastal ocean, Science, 308, 376-380, 2005.

Van Oost, K., Quine, T. A., Govers, G., De Gryze, S., Six, J., Harden, J. W., Ritchie, J. C., McCarty, G. W., Heckrath, G., Kosmas, C., Giraldez, J. V., Marques da Silva, J.R., and Merckx, R.: The importance of agricultural soil erosion on the global carbon cycle, Science, 318, 626-629, 2007.

Wallace, J. B., Whiles, M. R., Eggert, S., Cuffney, T. F., Lugthart, C. J., and Chung, K.: Long-term dynamics of coarse particulate organic matter in three Appalachian Mountain streams, J. N. Am. Benthol. Soc., 14, 217-232, 1995.

Ward, N. D., Keil, R. G., Medeiros, P. M., Brito, D. C., Cunha, A. C., Dittmar, T., Yager, P. L., Krusche, A. V., and Richey, J. E.: Degradation of terrestrially derived macromolecules in the Amazon River, Nat. Geosci. 6, 530-533, 2013.

Yoshimura, C., Fujii, M., Omura, T., and Tockner, K.: Instream release of dissolved organic matter from coarse and fine particulate organic matter of different origins, Biogeochemistry, 100, 151-165, 2010.

Yoon, B. and Raymond, P. A.: Dissolved organic matter export from a forested watershed during Hurricane Irene, Geophys. Res. Lett., 39, L18402, doi:10.1029/2012GL052785, 2012.

Zehetner, F., Lair, G. J., and Gerzabek, M. H.: Rapid carbon accretion and organic matter pool stabilization in riverine floodplain soils, Global Biogeochem. Cy., 23, GB4004, doi:10.1029/2009GB003481, 2009. 